\title{
Edible Landscaping for Urban Sustainability 1
}

\section{Eva C. Worden ${ }^{2}$}

Landscaping in the urban setting offers tremendous opportunity for contributing to sustainability. One such opportunity is edible landscaping. Edible landscapes are those that include plant species for human consumption.

\section{Benefits of Edible Landscapes}

\section{Greater Efficiency and Value}

Urban landscapes are human-dominated ecosystems that require considerable investment of time, space, money, and natural resources. Edible landscaping produces a valuable, multi-functional landscape, thus providing greater return on investment of resources while promoting sustainability. In addition to its efficiency, the edible landscape can be beautiful, equalling or surpassing the strictly ornamental landscape in aesthetic value.

\section{Improved Taste and Nutrition of Food}

Nutrient content and flavor in most plants is highest immediately after harvest. The edible landscape affords the ability to eat a food only minutes, rather than days or weeks, after harvest. In addition, many varieties that have been bred for exceptional flavor are available to the edible landscaper, far beyond those typically found in most urban food markets.

\section{Increasing Community Food Security}

Edible landscapes can increase urban sustainability by reducing a community's dependence on distant food sources. Distant sources of food generally involve unknown production systems and fuel economic systems that funnel money away from the communities they feed. It might be difficult to imagine producing enough food in an urban landscape to make a difference. However, urban centers around the United States and in other countries increasingly are finding that edible urban landscapes can be highly productive and profitable, contributing substantially to local communities.

\section{Management Considerations}

\section{Harvesting}

Harvesting can be the most rewarding part of having an edible landscape. However, harvesting can be difficult in some situations. If fruit trees are allowed to get too tall, fruit may be out of reach, even with the use of a ladder. Keeping up with the ripening of edible plants may require weekly, or even daily, monitoring during the harvest period. Some edible

1. This document is ENH971, one of a series of the Environmental Horticulture Department, Florida Cooperative Extension Service, Institute of Food and Agricultural Sciences, University of Florida. Original publication date May 2004. Visit the EDIS Web Site at http://edis.ifas.ufl.edu.

2. Eva Worden, Assistant Professor and Extension Specialist, Department of Environmental Horticulture, Fort Lauderdale Research and Education Center; Cooperative Extension Service, Institute of Food and Agricultural Sciences, University of Florida, Gainesville, 32611.

The Institute of Food and Agricultural Sciences (IFAS) is an Equal Employment Opportunity - Affirmative Action Employer authorized to provide research, educational information and other services only to individuals and institutions that function without regard to race, creed, color, religion, age, disability, sex, sexual orientation, marital status, national origin, political opinions or affiliations. For information on obtaining other extension publications, contact your county Cooperative Extension Service office. Florida Cooperative Extension Service / Institute of Food and Agricultural Sciences / University of Florida / Larry R. Arrington, Interim Dean 
species, if not harvested, can present management challenges. Certain trees might drop unharvested fruit to the ground which can be a nuisance. For example, unharvested, falling coconuts might be hazardous where people sit or walk, while mangos can attract vermin.

It is not uncommon to have excess fresh produce from an edible landscape. Highly perishable crops will require either quick processing, such as canning, freezing, or drying, or friends and neighbors to accept the abundance.

\section{Inputs}

Edible plants, like ornamental plants, do require maintenance. Some species require less maintenance than others, and planting the "right plant in the right place" (i.e., selecting species that thrive in existing environmental conditions) can keep maintenance requirements low. However, all species might need to be pruned, fertilized, watered, and monitored for pests periodically. Edible landscapes contain plants that are for human consumption. Therefore, special care should be taken in the selection of management inputs such as pesticides and fertilizers.

Special design approaches in edible landscaping include: crop rotation for annual and short-lived perennial species, in order to optimize fertility and to prevent pests and diseases; sequential planting to ensure a constant harvest; and integrating edible species with existing ornamental landscapes.

\section{Edible Can Be Environmentally Friendly}

The Florida Cooperative Extension Service has developed a program for "Florida-friendly" environmental landscape management known as "Florida Yards and Neighborhoods" (FYN). Edible landscapes can be managed easily under the FYN program. Information on this program can be obtained through county cooperative extension offices, and on the Internet at http://hort.ifas.ufl.edu/fyn/index.htm.

\section{The Edible Plant Palette}

Edible landscapes can include fruits, vegetables, and herbs. In Florida, the edible plant palette is vast. A small sampling of the many possible choices follows. Detailed plant characteristics can be found in the reference books listed below.

\section{Vegetables}

Lettuce (Lactuca sativa), cucumber (Cucumis sativus), tomato (Lycopersicon esculentum), broccoli (Brassica oleracea), eggplant (Solanum melongena), radish (Raphanus sativus), potato (Solanum tuberosum), corn (Zea mays), squash (Cucurbita spp.), green bean (Phaseolus vulgaris), pea (Pisum sativum), carrot (Daucus carota).

\section{Fruits}

Avocado (Persea americana), pineapple (Ananas comosus), blueberry (Vaccinium corybosum), carambola (Averrhoa carambola), lychee (Litchi chinensis), grape (Vitis vinifera), persimmon (Diospyros kaki), mamey (Mamey sapote), passion fruit (Passiflora edulis), papaya (Carica papaya), banana (Musa spp.), orange (Citrus sinensis), mango (Mangifera indica), acerola (Malpighia glabra), sapodilla (Manilkara zapota), strawberry (Fragaria x ananassa).

\section{Herbs}

Basil (Ocimum basilicum), oregano (Origanum vulgare), cilantro/coriander (Coriandrum sativum), rosemary (Rosmarinus officinalis), tarragon (Artemesia dracunculus), roselle (Hibiscus sabdariffa), chives (Allium tuberosum), peppermint (Mentha $\mathrm{x}$ piperita), ginger (Zingiber officinale), dill (Anethum graveolens), parsley (Petroselinum crispum), nasturtium (Nasturtium officinale).

\section{References}

Florida Home Grown 2: The edible landscape. Tom MacCubbin. 1989. Sentinel Books. Orlando, Florida.

The Complete Book of Edible Landscaping: Home landscaping with food-bearing plants and resource-saving techniques. Rosalind Creasy. 1982. Sierra Club Books. San Francisco, California.

Landscaping with Herbs. James Adams. 1987. Timber Press. Portland, Oregon. 
The New Oxford Book of Food Plants: A guide

to the fruit, vegetables, herbs and spices of the world.

J.G. Vaughan and C.A. Geissler. 1997. Oxford

University Press. New York. 